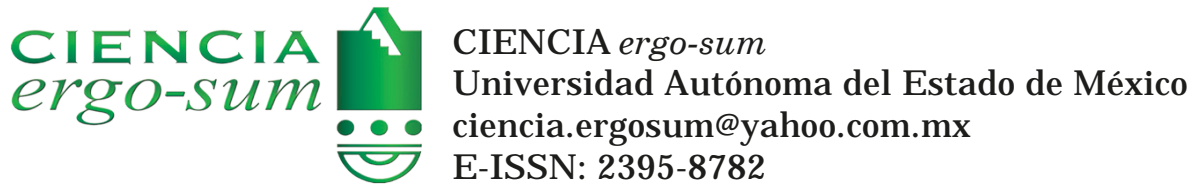

\title{
Detection of desirable areas for urban growth through GIS and OWA: the case of Culiacan and Navolato
}

Uriarte Adrián, J osé J esús; Plata Rocha, Wenseslao; Romero Andrade, Rosendo; Corrales Barraza, Gabriela; Beltrán González, J osé C.; Remond Noa, Ricardo

Detection of desirable areas for urban growth through GIS and OWA: the case of Culiacan and Navolato

CIENCIA ergo-sum, vol. 27, núm. 2, julio-octubre 2020|e85

Universidad Autónoma del Estado de México, México

Esta obra está bajo una Licencia Creative Commons Atribución-NoComercial-SinDerivar 4.0 Internacional.

Uriarte Adrián, J . J ., Plata Rocha, W., Romero Andrade, R., Corrales Barraza, G., Beltrán González, J . C. y Remond Noa, R. (2020). Detection of desirable areas for urban growth through GIS and OWA: the case of Culiacan and Navolato. CIE NCIA ergo-sum, 27(2). https://doi.org/10.30878/ces.v27n2a6 


\title{
Detection of desirable areas for urban growth through GIS and OWA: the case of Culiacan and Navolato
}

Detección de áreas deseables para el crecimiento urbano mediante SIG y OWA: el caso de Culiacán y Navolato

\author{
José Jesús Uriarte Adrián \\ Universidad Autónoma de Sinaloa, México \\ jesusuriarte@uas.edu.mx \\ (1) http://orcid.org/0000-0002-0936-0454 \\ Wenseslao Plata Rocha \\ Universidad Autónoma de Sinaloa, México \\ wenses@uas.edu.mx \\ (D) http://orcid.org/0000-0002-9469-7886 \\ Rosendo Romero Andrade \\ Universidad Autónoma de Sinaloa, México \\ r.romero11@info.uas.edu.mx \\ (1) http://orcid.org/0000-0003-3786-0576 \\ Gabriela Corrales Barraza \\ Universidad Autónoma de Sinaloa, México \\ gabriela.corrales@info.uas.edu.mx \\ (D) http://orcid.org/0000-0003-4182-5458 \\ José C. Beltrán González \\ Universidad Autónoma de Sinaloa, México \\ jose.beltran@info.uas.edu.mx \\ (1) http://orcid.org/0000-0002-2758-5980 \\ Ricardo Remond Noa \\ Universidad de La Habana, Cuba \\ remond@geo.uh.cu \\ (D) http://orcid.org/0000-0002-6969-3453
}

\section{Resumen}

Debido al crecimiento acelerado de superficies artificiales, en las últimas dos décadas se ha observado un creciente interés en los cambios de uso de suelo, lo que hace necesario establecer modelos que generen planes de desarrollo óptimo y sustentable. De este modo, se busca identificar los espacios potencialmente más aptos para acoger el crecimiento urbano mediante simulaciones geoespaciales que integran a los Sistemas de Información Geográfica y OWA (Ordered Weighted Average). Para conseguirlo, se propone una metodología de análisis de sensibilidad a los resultados para comprobar su robustez a la variabilidad de los pesos de los factores de entrada, basada en clasificación por histogramas y distancias. Las propuestas de selección muestran un considerable porcentaje de acuerdo con al área programada.

Palabras CLAVE: evaluación multicriterio, crecimiento urbano, simulación de escenarios.

\section{Abstract}

Due to an accelerated growth of artificial surfaces, an increasing interest in the changes on land use has been detected in the last decade, making it necessary to propose models able to create plans of optimal and sustainable development. The goal of this work is to identify the potentially most suitable spaces for urban growth, through geospatial simulations which integrate the Geographic Information Systems and OWA (Ordered Weighted Average). We propose a sensitivity analysis methodology to the results in order to assess their robustness with respect to the input values' weights variability, based on histograms and distances classification. Finally, the selection proposal shows a considerable percentage according to the planned area.

KEYWORDS: Multicriteria evaluation, urban growth, simulation of scenarios. 


\section{INTRODUCTION}

If Culiacan and Navolato municipalities, both located in the state of Sinaloa, Mexico, are compared to the rest of the state's municipalities, it can be detected that the former areas have had the greatest rates of change in land use. This increased Sinaloa's artificial surface in 4.17\% (35 678 hectare) since 1993 and, if such tendency continues, it is expected to further increase 4.4\% (37 656 hectare) for 2030 (Corrales Barraza, 2017). These changes could be considered as irreversible and the impact varies in function of the land occupation presented. Then, the development patterns have consequences in aspects as the sustainability; therefore, it is necessary to acquire tools that allow simulations of different scenarios, in order to analyze where we are going, considering the speed at which the changes are currently happening (Roura-Pascual et al., 2010). Because of this, the development of geospatial models has increased significantly and the behavior of urban areas has been analyzed to promote a sustainable growth and prevent a disorganized urban sprawl (Comisión Europea, 1999; Phua, \& Minowa, 2005; Naghdizadegan et al., 2013; Mogaji et al., 2014; Furtado, \& Eberhardt, 2015).

On this matter, the development of tools and methodologies that can be employed on the analysis of the territory's constant changes made essential the adoption of the Geographic Information Systems (SIG) and the Multicriteria Evaluation (MCE). The latter has demonstrated great capability and efficiency in the design of optimal models or desirable process on territory planning (Barredo, \& Bosque-Sendra, 2009; Plata et al., 2010; Plata-Rocha et al., 2013; Gómez-Delgado et al., 2014; Tan et al., 2015; Feng et al., 2016).

Within different MCE techniques (Gómez, \& Barredo 2005), the Ordered Weighted Average (OWA) is the most frequently employed technique (Jiang, \& Eastman, 2000; Malczewski, 2002; Chang et al., 2008; Boroushaki, \& Malczewski, 2008). This technique represents the join between a method of rigid MCE (as the weighted linear combination) and fuzzy logic, resulting a technique that allows to control the risk and the uncertainty associated to any decision-making.

We propose a methodological scheme to perform simulations of scenarios and sensitivity analysis. Thus, different factors related to environmental, economic and social criteria interacting with the OWA method and GIS need to be considered. Later, a sensitivity analysis to assess the behavior of the model is performed. The main purpose is to carry out several simulations of the urban growth under a sustainable scenario allowing us to identify the areas potentially suitable with the capacity of new urban areas in a medium-term, having 2011 as the base year and 2030 as the future horizon following the projections of The State plan of urban development and the state program of land-use planning (IMPLAN, 2015).

\section{STUDY AREA}

The study area is located in the center of the state of Sinaloa which has 18 municipalities, among which Culiacan stands out as capital of the state, having the biggest population and surface. On the other hand, Navolato is the youngest municipality of the state (separated of Culiacan in 1982), where the capital receives the same name as the township, sharing the urban area with Culiacan which has been developed around the roads that connect these two zones.

The townships of Culiacan and Navolato are located between the parallels $24^{\circ} 02^{\prime}$ and $25^{\circ} 59^{\prime}$ North latitude and $106^{\circ} 52^{\prime}$ and $108^{\circ} 04^{\prime}$ West longitude with an altitude between 0 and $800 \mathrm{~m}$, the state is adjacent with the settlements of Angostura, Mocorito, Badiraguato and the state of Durango; to the East of the state of Durango and the municipalities of Cosala and Elota; to the South with the city of Elota and the Pacific Ocean (figure 1).

The municipality of Culiacan covers $10.96 \%$ of the surface of the state and has 1483 communities (INEGI, 2014); while, the municipality of Navolato covers $3.71 \%$ of the surface with 489 communities. Both townships have $14.67 \%$ of the surface of the state with $8760.74 \mathrm{~km}^{2}$, where there are 994241 inhabitants (INEGI, 2014). 
The greatest percentage (15.80\% approximately) of inhabitants lives in the capital cities of Culiacan and Navolato with 858638 and 135603 inhabitants, respectively (Anon, 2010).

The region where the municipalities of Culiacan and Navolato are located has a diverse use of natural soil (forestry, water bodies, among others) and artificial soil. The latter's use is a result of the anthropization process occurred in the territory; it has principally appeared due to an intense dynamic caused by the agronomic potential of the region, for agricultural activities as well as investments related to tourism projects in the Sea of Cortes (Corrales Barraza, 2013).

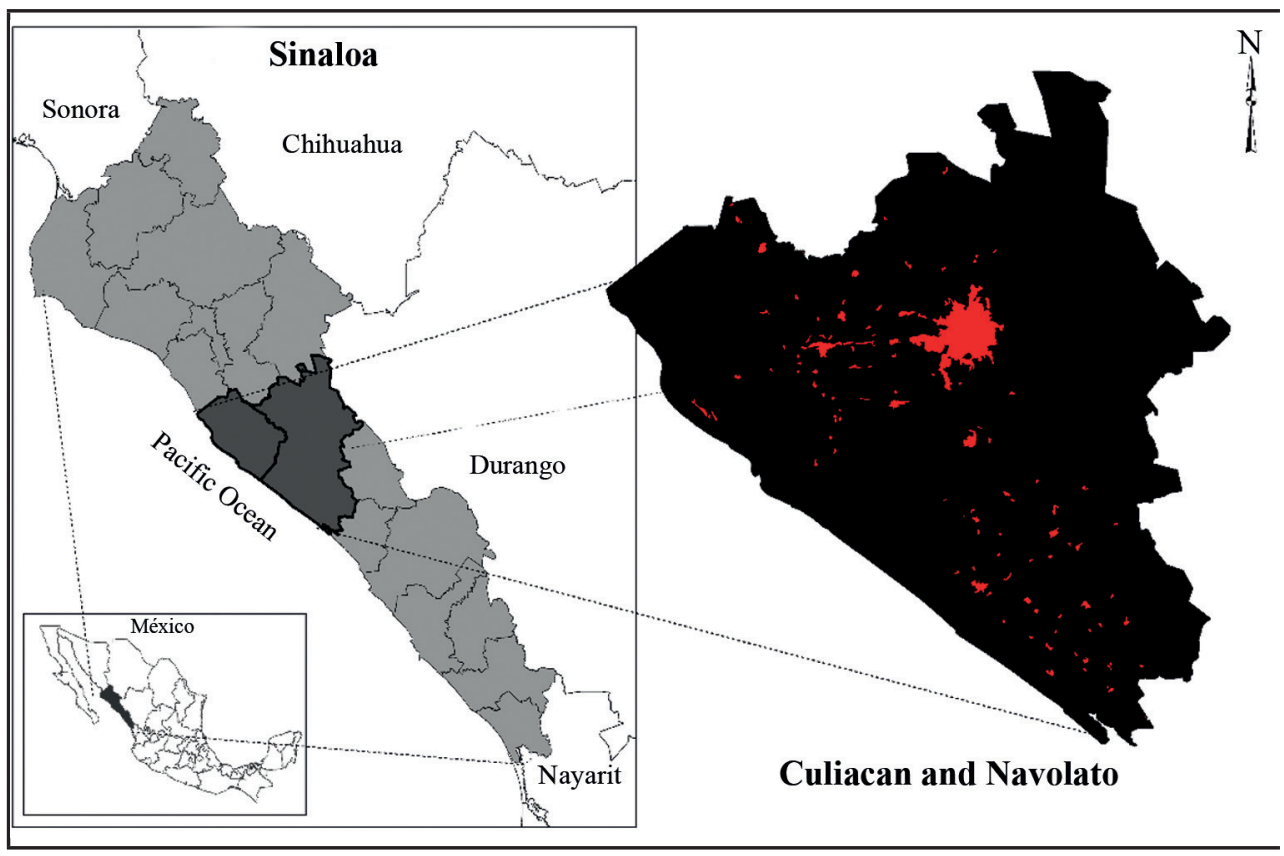

FIGURE 1

Geographical localization of the study area

Source: elaboration based on INEGI maps.

\section{1. Characterization of the urbanization of Culiacan and Navolato}

The municipality of Culiacan is the main actor in the state's urbanization, not only because of its geographical location, but also because of its municipal seat where the city of Culiacan is the capital of the state, generating greater dynamics in the municipality of Culiacan. For the year 2000, the urban dynamics of Culiacan promotes the territorial functioning of the municipal urban structure, manifested by the urban dynamics that are determined by the location of the city and urban locations in the relationship with the city of Culiacan. Thus, in the central zone of the municipality, the city of Culiacan and the receivership Costa Rica and the urban localities of El Diez, Culiacancito, Limon de los Ramos and Adolfo Lopez Mateos make up the central urban structure, which functionally integrates the administrative territory. Also, in the coastal zone and the San Lorenzo River area, the urban areas of El Dorado, Leopoldo Sanchez Celis, Quila and Pueblos Unidos, form the urban structure of the coast. The central urban is the region with greater urban dynamics in the municipality of Culiacan.

From 1984 to 2000, urbanization in the municipality of Navolato has been mainly characterized by a rural population profile with a tendency for the population to concentrate in the city of Navolato and Benito Juarez. This is because primary economic activities contribute to the dispersed localities in the municipal territory and because this is articulated through an urban structure that is led by the city of Navolato, which is interconnected with the urban structure of the adjacent municipality of Culiacan. The state's tendency to multiply the number of localities does not manifest itself in the municipality of Navolato, since it presents a slight increase when 
going from 301 to 329 localities. However, it highlights the phenomenon of population dispersion in the territory, given that the total municipal urban population is concentrated in only six localities. Likewise, the state tendency to concentrate the population in the municipal seat is maintained, although this phenomenon is minimal, since the city of Navolato concentrates only $16 \%$ of the municipal population in 1990 and $18 \%$ in 2000 (Roldán López, 2006).

\section{Materials and methods}

\section{1. Data}

The variables employed to generate the simulation of the model were displayed by using the cartographic information of vegetation and land use, soil type, hydrography, roads, altitude and slope as reference; all of this was obtained through the web page (http://www.inegi.org.mx/) of the National Institute of Statistic and Geography (INEGI, 2017).

\section{Methodology}

The methodology was implemented mainly in three stages with the purpose to evaluate the land aptitude for urban sprawl. A geospatial simulation of a desirable land-use model based on Multicriteria Evaluation (MCE) and Ordered Weighted Average (OWA) techniques was performed.

Later, to accomplish the greatest degree of uncertainty, a Sensibility Analysis (SA) through the use (or combination) of weights was implemented, these measurements were obtained considering the expertise of different experts on this field, following the criteria for a sustainable scenario. Finally, through different simulated aptitude maps, those areas most susceptible of urban growth were only identified, regardless of the aptitude range presented (binary, growth or not growth maps), carrying out different classification by histograms and distances through aptitude maps recently produced.

The information presented on annexed table 1, has a pixel side of $100 \mathrm{~m}$ and it is represented in the cartographic projection UTM Zone 13 North (Corrales Barraza, 2013). The index of marginalization was considered, which models the level of education, housing status and economic income of a population, determining several factors such as the behavior of people based on culture, traditions and beliefs, showing that higher the marginalization index the lower the growth capacity; this information was considered by the National Population Council (CONAPO).

\section{1. Geospatial simulation}

In order to carry out the geospatial simulation, some of the stages of the methodology proposed by Gómez, \& Barredo (2005) were taken as reference. Such stages are the generation of alternatives (factor modeling), the elaboration of the decision matrix (weighing) and the selection of the evaluation method(s), the selection of alternatives and the sensitivity analysis. Below we describe the stages of the simulation process for the urbanland surface with more detail.

\section{2. Selection, normalization and weighting of criteria}

First, a spatial variables selection related to the growth dynamics of the urban-land was performed, taking as reference some factors and criteria used by (Jiang, \& Eastman, 2000; Hu, \& Lo, 2007; Al-Shalabi et al., 2006; Barredo, \& Bosque-Sendra, 2009; Plata-Rocha et al., 2013); this was performed attempting to represent the greatest variables number which influence the urban growth. 
It is important to note that only the information available at the moment of this study was used. Also, we carried out a survey applied to experts in different research areas (geography, GIS, land-use planning and economical and social geography), who gave their opinions about which variables it was worth to consider.

This way, the factors generated through selected variables, help to describe the ideal condition to simulate an optimal urban growth considering a sustainable scenario. Ten variables were chosen: proximity to human settlement, proximity to natural vegetation, proximity to pastureland, proximity to irrigation agriculture, proximity to rainforest agriculture, planned urban area, proximity to roads, slopes, rivers and the index of marginalization. Additionally, we selected a series of restrictions in urban growth, where the alternatives that are excluded from the analysis are not considered, that is, areas that cannot be urbanized (rivers, roads, existent urbanized areas and protected areas) are neglected.

An important aspect about this type of studies, where, they are distinct factors, variables and criteria, is data standardization. Such data is expressed with different measurements scales; thus, a data standardization is employed here using fuzzy membership functions (linear and $j$-shape) and adjusting the original values between given minimum and maximum limits (0-255) (Eastman, 2012; Drobne, \& Lisec, 2009; Malczewski, 2004).

According to one of the multicriteria evaluation principles, the dataset must represent all the dimensions of the phenomenon studied, in a relevant, minimal and no-redundant way. This implies that factors contributing the same information should not be allowed, since, some of the criteria considered in the study could be overvalued, if there is more than one factor that is assessing its adequacy (Gómez, \& Barredo, 2005).

Thus, to avoid the problem of the redundancy, all the normalized problems were submited to a correlation analysis, in order to find which ones were specially related. The correlation analysis evaluates the degree of association that exists between the factors, this process was realized using the Pearson's correlation coefficient (Pearson, 1920). This coefficient allows the elimination of variables, where, the correlation coefficients are high, according to Guilford (1954); in this way, it is reducing the dimensionality of the number of the input values.

\section{3. Assignment of the weights}

The values assigned to the factors' weights were obtained from a survey applied to geography researchers, specialists in urban areas studies (geography, GIS, land-use planning and economical and social geography).

The group of researchers consulted was formed by 14 experts that, with their different points of view (economic, environmental, social; essential for a sustainable scenario), assigned different orders weight to each of the factors under different assumptions of preference in the choice of urban sites (table 3 ).

The Saaty's pairwise comparison method is applied later. This method compares the importance of each factor over the others, establishing the relative importance (weight) of each of them and providing a quantitative measurement of the judgment values between pairs of factors, also, the calculation of the consistency index, that indicates whether the relationship between the weights is correct or has some degree of error (Saaty, 1987).

\section{4. Evaluation method}

We used the OWA technique to perform the final evaluation of the alternatives since it offers a full spectrum of decision strategies (Eastman, 2012). Specifically, it allows to manage the risk and the uncertainty associated to any decision making. The OWA technique works as an operator for maps combination. It associates a spatial location $i$ (a pixel, raster format) and two sets of weighs for a set of $n$ factors, the ones with relative importance to 
the factor $v=v_{1}, v_{2}, \ldots, v_{n}$, tal que $v_{j} \in[0,1], j=1,2, \ldots, n y \sum_{j=1}^{n} v_{j}=1$ and the ones with order $u=u_{1}, u_{2}, \ldots$, $u_{n}$, tal que $u_{j} \in[0,1], \mathrm{y} \sum_{j=1}^{n} u_{j}=1$, given the values of the factors $a_{i 1}, a_{i 2}, \ldots, a_{\square}$ in the position $i$ (Malczewski, 2006). Then, the calculation of OWA is obtained from the following equation:

$$
O W A_{i}=\sum_{j=1}^{n}\left(\begin{array}{c}
u_{j} v_{j} \\
\sum_{j=1}^{n} u_{j} v_{j}
\end{array}\right) z_{i}, j
$$

Where $z_{i 1} \geq z_{i 2} \geq \ldots \geq z_{i j}$ is the sequence obtained to reorder the values of the factors $a_{i 1}, a_{i 2}, \ldots, a_{i j}$ and $u_{j}$, that is, the reorder weigh factor $j$ according to the value of the factor $z_{i j}$ (Malczewski et al., 2003).

It is important to point out the existence of the two types of weights considered, the weights and the order of the factors. The former refers to the factor's evaluation, in order to indicate the compensation that exists between them, that is, all the $i$ positions of the factor $j$ that assign the same weight $v_{j}$. Depending on the weight order, each factor is assigned pixel by pixel, and it is associated with the value of the factor on the position $i$ in decreasing order, regardless of the map or factor from which that value comes from (Malczewski, 2006).

\section{5. Sensitivity analysis}

For this step, all the proposed weights were determined under the same proposed weights; after, it was sought to obtain different maps of adequacy or aptitude for the growth of urban surfaces. Using these maps, the pixels with the greatest aptitude were chosen, searching to accomplish a determinate surface demand.

Based on the Dynamic of System technique, Corrales Barraza (2013) simulates a surface demand of land use for sustainability until the year 2030, where a surface demand of 676 ha is obtained as urban results (using the sustainability scenario).

The results of perspective simulations need to be treated very carefully since it is not possible to determine/ stablish with a reliable degree of accuracy (Barredo, \& Gómez, 2008). In the Sensitivity Analysis (SA), the consequences that result from the changes of a model's parameters is analyzed. Thus, it is possible to determine a reliability degree (Qureshi et al., 1999). Given that the future is inherently uncertain, it is possible to explore different alternatives through a sensitivity analysis (Van Der Heijden, 2005). In other words, it is feasible to evaluate the same objective, realizing alternatives models as in this study.

Hence, in this study, an AS with the purpose to find the pixels (areas) more stable to variations was realized.

Here, we performed multiple simulations of each objective, considering different values for the input parameters in each simulation. This allows one having as many finals simulations as the number of variations made (the different weights given by the survey); therefore, producing a higher number of simulated maps to analyze the ideal pixels. It is plausible to assume that the surface chosen in/by this way will be the most reliable.

\subsection{Selection of the areas of optimal urban growth}

Considering the different aptitude maps simulated and following the series of steps shown in figure 2, we obtained a candidate for the best surface for the development of urban growth. First, the average value of all the aptitude maps was calculated in order to classify the maps equitable.

Later, each aptitude map was classified in one of 5 categories (according to its aptitude level) employing the Natural Breaks (NB) technique (Jenks, 1967). This technique is mainly based on the summation of the standard deviations of the category.

Only the pixels with the highest category are selected from the classification. The result of the best category selection of each map is overlapped to generate a Frequency Map (FM), which contains the frequency in which 
the pixel appears in the different selections, this is, the binary maps are added only with the cells that have a category value of 5 .

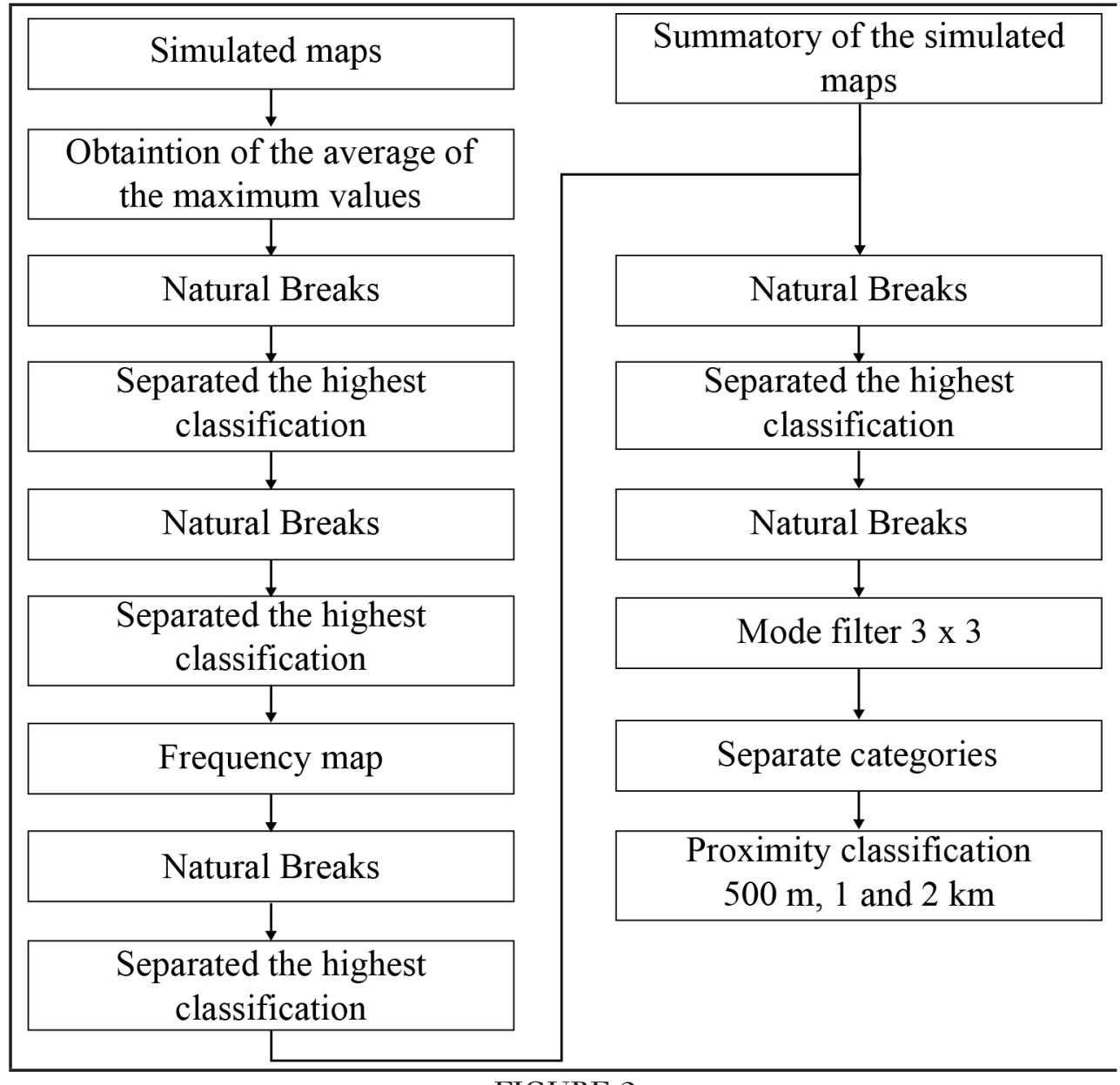

FIGURE 2

Methodology used to obtain the best surface

Source: own elaboration.

After the previous procedure, an NB classification is applied to the FM, selecting again the highest category. Then, the generation of a summation map is necessary; through the summation of the aptitude values of all the simulated maps (for each pixel) and after an overlap of the maps, the values of the summation of the selected pixels in the last classification process are obtained. Finally, the final selection of the pixels contained on the best aptitude values is performed.

Likewise, another proposal to determine the pixel selection is through the distance, considering it as a relevant characteristic, in order to observe the most nearby/remote area for a preferential location. Thus, it is necessary to follow the stages of the previous analysis, but performing a new classification process by swapping the aptitude level selection with a classification by Natural Breaks and then choosing the best category this time. Afterward, a mode filter with a window of $3 \times 3$ pixels to compact the areas and eliminate isolated pixels is applied, selecting only the cells with the highest category and applying a mode filter for a second time. Thereafter, for the distance's analysis, the highest category was considered as the initial position, in which the pixels had the most potential---. Then, the distance classification achieves to integrate, those set of pixels found, through the generation of a radio quest for distances of $500 \mathrm{~m}, 1 \mathrm{~km}$ and $2 \mathrm{~km}$.

Thus, observing the remaining classes $(4,3,2,1)$, the pixels are classified as a set, not as individual, according to the distance to the initial selection. For the final map of this process, you need to separate the aptitude value 
into very high for the pixels in the base region, high for those areas located no more than $500 \mathrm{~m}$, average for distances up to $1 \mathrm{~km}$, low for areas no more than $2 \mathrm{~km}$ and very low for major distances.

\section{Results}

\section{1. Normalization and correlation analysis}

We now present the functions used to normalize the nine factors (aiming to standardize the range of the data). We also show the coefficient obtained through the correlation analysis (table 2).

TABLE 2

Fuzzy membership and weights (survey to experts) for each input factor ( $\mathrm{MG}=$ monotonically growing, $\mathrm{MD}=$ monotonically decreasing $)$

\begin{tabular}{|lc|}
\hline \multicolumn{1}{|c|}{ Factors } & Fuzzy function \\
\hline Proximity to human settlement & Lineal (MG) \\
Proximity to natural vegetation & Lineal (MG) \\
Proximity to pastureland & Lineal (MG) \\
Proximity to irrigation agriculture & Lineal (MG) \\
Proximity to rainforest agriculture & Lineal (MG) \\
Planned urban area & Lineal (MD) \\
Proximity to roads & Lineal (MG) \\
Slopes & J-Shape (MG) \\
Proximity to rivers & Lineal (MD) \\
Margination index & Inverse distance weighting (IDW) \\
\hline
\end{tabular}

Source: own elaboration.

Assessing the results we can observe that the most correlated factors are the proximity to rainforest agriculture and the proximity to roads with the proximity to nature vegetation with 0.92 and -0.93 respectively. However, due to the significance of the factors' characteristic information and for this specific case where few factors were used, none of them were eliminated. Figure 3 shows the final normalized factors.

\section{2. Assignment of the weights}

We use the Saaty's pairwise comparison method to assign weights to the factors; the final weight was obtained through the order of the weighs given for each factor. Altogether, we used 31 scenarios under different criteria (all of them for a sustainable scenario) for each factor. Table 3 shows the final weights used in each proposed scenario. The consistency indicator of each scenario was better or equal to 0.1 . Thus, the proportion between all the weights proposed is considered correct.

\section{3. Evaluation method for the adequacy maps obtainment}

After the reiterative application of the ordered weighted average technique, we modified the weights according to what the experts said. 31 aptitude or adequacy maps were gathered for the development of urban growth. In order to identify the most feasible areas to house urban growth. Some examples are shown as examples in figure 4. 


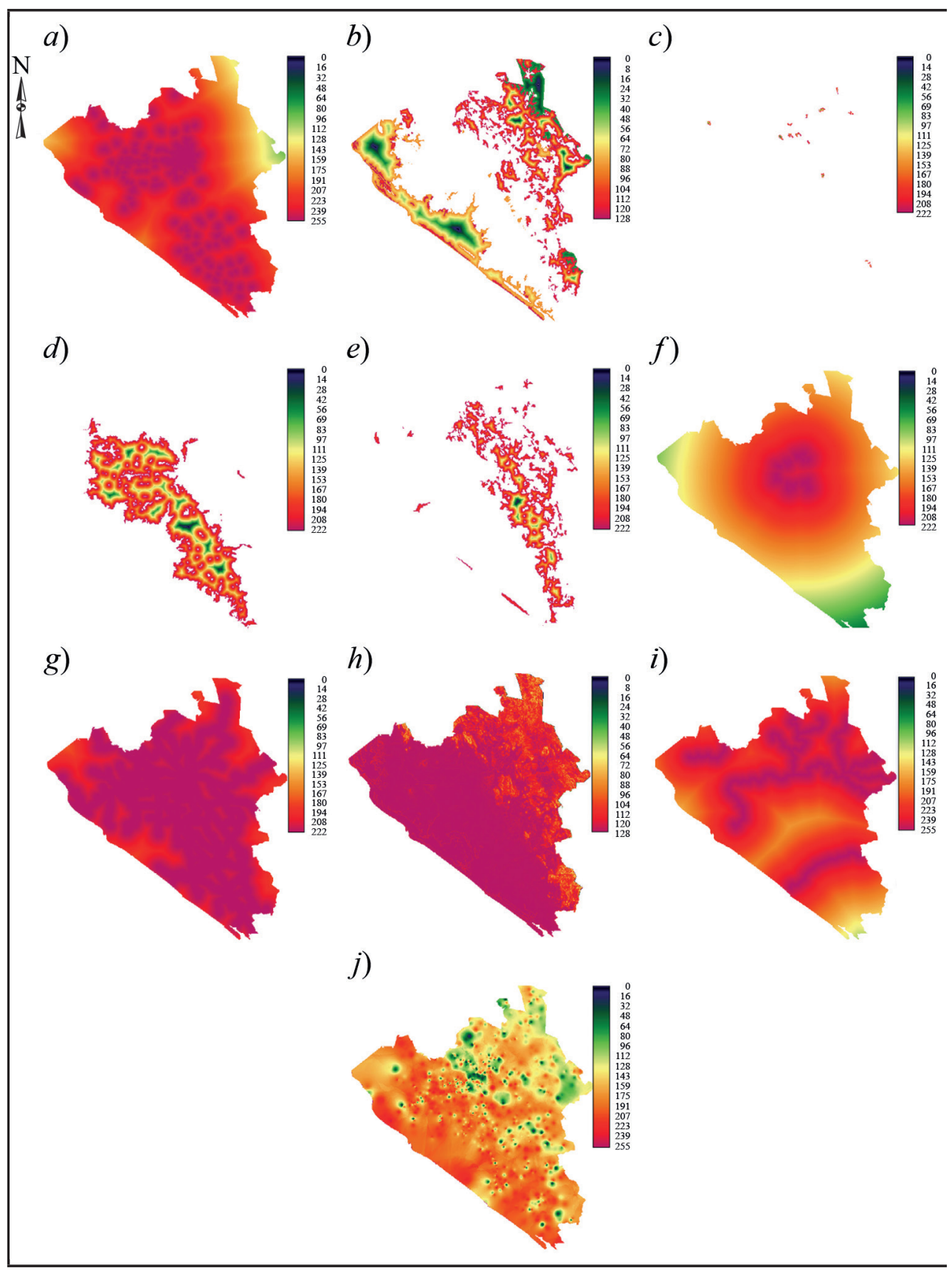

FIGURE 3

Final normalized factors: a) Proximity to human settlement, $b$ ) Proximity to natural vegetation, c) Proximity to pastureland, $d$ ) Proximity to irrigation agriculture, $e$ ) Proximity to rainforest agriculture, $f$ ) Planned urban area, $g$ ) Proximity to roads, $h$ ) Slopes, $i$ ) Proximity to rivers and $j$ ) Margination index. (Created by the author).

\section{4. Selection of the optimal areas for urban growth}

The proposed procedures allow us to detect and choose the desirables areas for urban growth. Through 31 simulated aptitude maps, the first stage consisted in the Natural Breaks classification, where the frequency map was obtained. Such frequency map adds the occurrence of each pixel in its same position in all the different simulations (figure 5). To the FM, an NB process is used, and the highest pixel of the classification are selected. 
TABLE 3

Weights used in each of the 31 scenarios. This table was made from the survey of experts where each one of them, and according to their specialty, proposed a scenario assigning a weight (0-1) to each factor. Highlighting the importance of certain factors for each scenario.

\begin{tabular}{|c|c|c|c|c|c|c|c|c|c|}
\hline & $\begin{array}{l}\text { Proximity } \\
\text { to human } \\
\text { settlement }\end{array}$ & $\begin{array}{l}\text { Proximity } \\
\text { to natural } \\
\text { vegetation }\end{array}$ & $\begin{array}{l}\text { Proximity } \\
\text { to pasture } \\
\text { land }\end{array}$ & $\begin{array}{l}\text { Proximity } \\
\text { to irrigation } \\
\text { agriculture }\end{array}$ & $\begin{array}{l}\text { Proximity } \\
\text { to rainforest } \\
\text { agriculture }\end{array}$ & $\begin{array}{c}\text { Planned } \\
\text { urban area }\end{array}$ & $\begin{array}{c}\text { Proximity } \\
\text { to roads }\end{array}$ & Slopes & $\begin{array}{c}\text { Proximity } \\
\text { to rivers }\end{array}$ \\
\hline 1 & 0.30 & 0.0050 & 0.0050 & 0.0050 & 0.0050 & 0.40 & 0.10 & 0.03 & 0.15 \\
\hline 2 & 0.25 & 0.0025 & 0.0025 & 0.0025 & 0.0025 & 0.35 & 0.15 & 0.04 & 0.20 \\
\hline 3 & 0.20 & 0.0025 & 0.0025 & 0.0025 & 0.0025 & 0.35 & 0.15 & 0.09 & 0.20 \\
\hline 4 & 0.15 & 0.0075 & 0.0075 & 0.0075 & 0.0075 & 0.30 & 0.15 & 0.07 & 0.30 \\
\hline 5 & 0.10 & 0.0100 & 0.0100 & 0.0100 & 0.0100 & 0.25 & 0.16 & 0.10 & 0.35 \\
\hline 6 & 0.15 & 0.0000 & 0.0000 & 0.0000 & 0.0000 & 0.20 & 0.35 & 0.10 & 0.20 \\
\hline 7 & 0.15 & 0.0000 & 0.0000 & 0.0000 & 0.0000 & 0.25 & 0.30 & 0.10 & 0.20 \\
\hline 8 & 0.25 & 0.1000 & 0.1000 & 0.0250 & 0.0500 & 0.10 & 0.20 & 0.15 & 0.03 \\
\hline 9 & 0.20 & 0.0250 & 0.0250 & 0.0250 & 0.0250 & 0.15 & 0.25 & 0.15 & 0.15 \\
\hline 10 & 0.20 & 0.0500 & 0.1000 & 0.0500 & 0.0500 & 0.10 & 0.20 & 0.10 & 0.15 \\
\hline 11 & 0.20 & 0.0375 & 0.0375 & 0.0375 & 0.0375 & 0.15 & 0.15 & 0.20 & 0.15 \\
\hline 12 & 0.30 & 0.0250 & 0.0250 & 0.0250 & 0.0250 & 0.10 & 0.10 & 0.30 & 0.10 \\
\hline 13 & 0.20 & 0.0500 & 0.0500 & 0.0500 & 0.0500 & 0.10 & 0.20 & 0.20 & 0.10 \\
\hline 14 & 0.20 & 0.0250 & 0.0500 & 0.1000 & 0.0250 & 0.25 & 0.20 & 0.05 & 0.10 \\
\hline 15 & 0.20 & 0.0500 & 0.0300 & 0.0600 & 0.0500 & 0.25 & 0.25 & 0.06 & 0.05 \\
\hline 16 & 0.15 & 0.0500 & 0.0500 & 0.2000 & 0.2000 & 0.10 & 0.15 & 0.04 & 0.06 \\
\hline 17 & 0.05 & 0.2500 & 0.1500 & 0.0500 & 0.0500 & 0.05 & 0.05 & 0.15 & 0.20 \\
\hline 18 & 0.10 & 0.0500 & 0.2000 & 0.0400 & 0.2000 & 0.10 & 0.05 & 0.13 & 0.13 \\
\hline 19 & 0.15 & 0.1000 & 0.1000 & 0.0500 & 0.0500 & 0.20 & 0.05 & 0.25 & 0.05 \\
\hline 20 & 0.20 & 0.1000 & 0.1000 & 0.1000 & 0.1000 & 0.15 & 0.10 & 0.05 & 0.10 \\
\hline 21 & 0.15 & 0.3000 & 0.0500 & 0.1000 & 0.0500 & 0.10 & 0.10 & 0.10 & 0.05 \\
\hline 22 & 0.10 & 0.0500 & 0.0500 & 0.1000 & 0.0500 & 0.20 & 0.30 & 0.10 & 0.05 \\
\hline 23 & 0.30 & 0.1000 & 0.0500 & 0.0500 & 0.0500 & 0.10 & 0.10 & 0.15 & 0.10 \\
\hline 24 & 0.15 & 0.1000 & 0.0500 & 0.1000 & 0.1500 & 0.05 & 0.05 & 0.20 & 0.15 \\
\hline 25 & 0.25 & 0.0700 & 0.0500 & 0.1500 & 0.0500 & 0.05 & 0.25 & 0.10 & 0.03 \\
\hline 26 & 0.20 & 0.0250 & 0.0250 & 0.0250 & 0.0250 & 0.15 & 0.30 & 0.15 & 0.10 \\
\hline 27 & 0.20 & 0.1000 & 0.0300 & 0.1000 & 0.0700 & 0.10 & 0.20 & 0.15 & 0.05 \\
\hline 28 & 0.10 & 0.0400 & 0.0200 & 0.0200 & 0.0200 & 0.30 & 0.20 & 0.15 & 0.15 \\
\hline 29 & 0.04 & 0.0400 & 0.0400 & 0.0400 & 0.0400 & 0.20 & 0.20 & 0.20 & 0.20 \\
\hline 30 & 0.04 & 0.0300 & 0.0300 & 0.0500 & 0.0500 & 0.15 & 0.15 & 0.25 & 0.25 \\
\hline 31 & 0.10 & 0.0000 & 0.0000 & 0.1000 & 0.1000 & 0.20 & 0.15 & 0.20 & 0.15 \\
\hline
\end{tabular}

Source: own elaboration. 
Also, a map with the summation of the aptitude values (0-255) of all the simulations was created, for each pixel, and for all the scenarios; then, through all the previously selected pixels, their summation values were obtained. Later, the Natural Break classification process was applied two times, always selecting the highest category, until acquire a map with 5 aptitude category: very high, high, average, low and very low, which, contain 280,708,1290,1 647 and 1807 ha (where a pixel in the image is equivalent to $100 \times$ $100 \mathrm{~m})$, respectability.

Of the resultant categories, the highest category, containing 280 ha was selected. Besides, due to the necessity of selecting 676 ha at the moment to consider only the best category (quite high), it is not possible to satisfy the surface demand; however, it is possible to exceed the necessary surface of 988 ha if the following best (high) categories are merged.

As stated above, the selection by distance was considered as the initial position, the best classification by NB (very high) containing the pixels with the best potential (aptitude), later, it was attempted to integrate those set of pixels found through the generation of a radio quest for a distance of $500 \mathrm{~m}, 1 \mathrm{~km}$ and $2 \mathrm{~km}$.

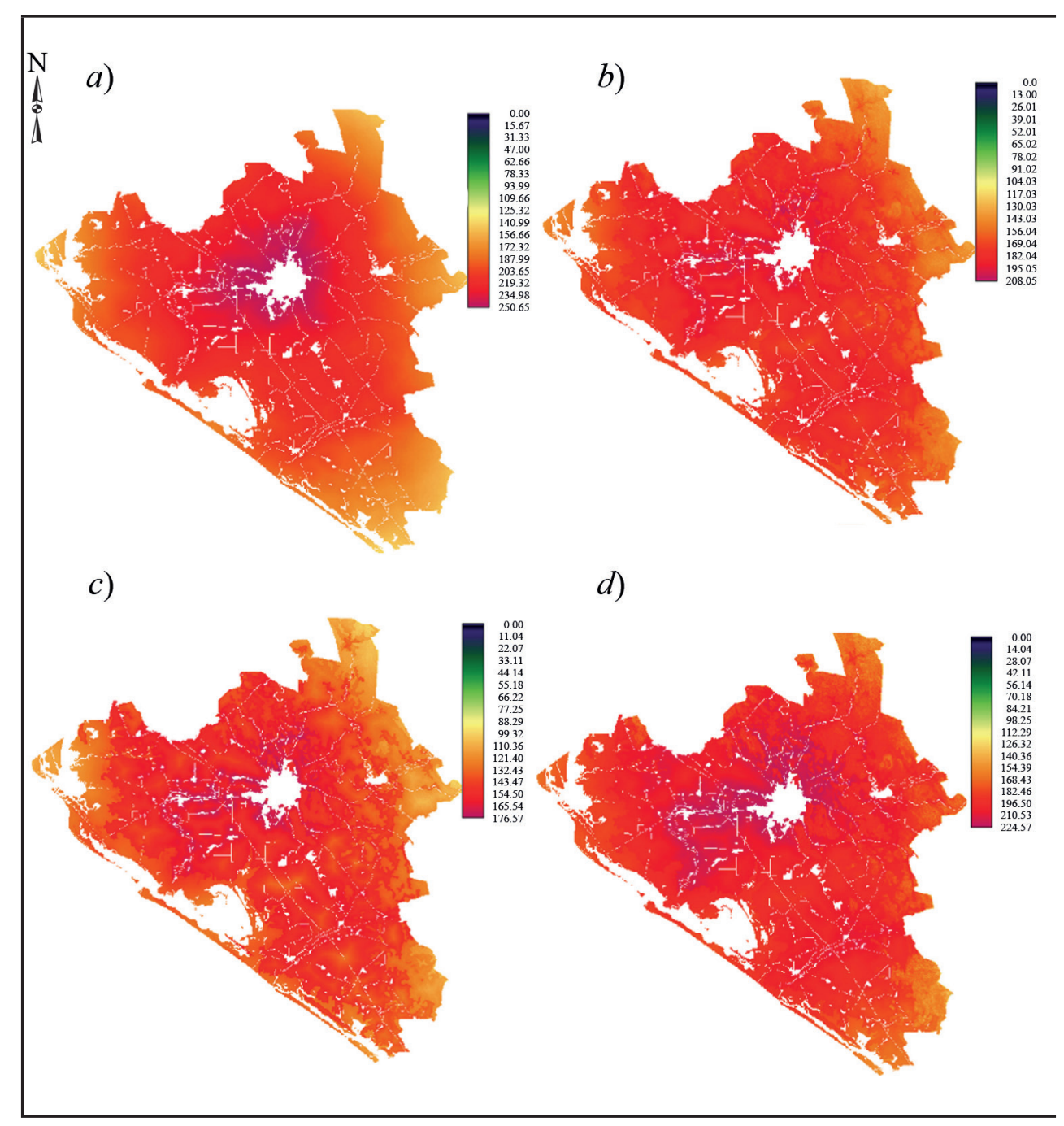

FIGURE 4

Different aptitude maps resulting of OWA: a) scenario 1,b) scenario 10, c) scenario 20,d) scenario 30 . Source: own elaboration. 


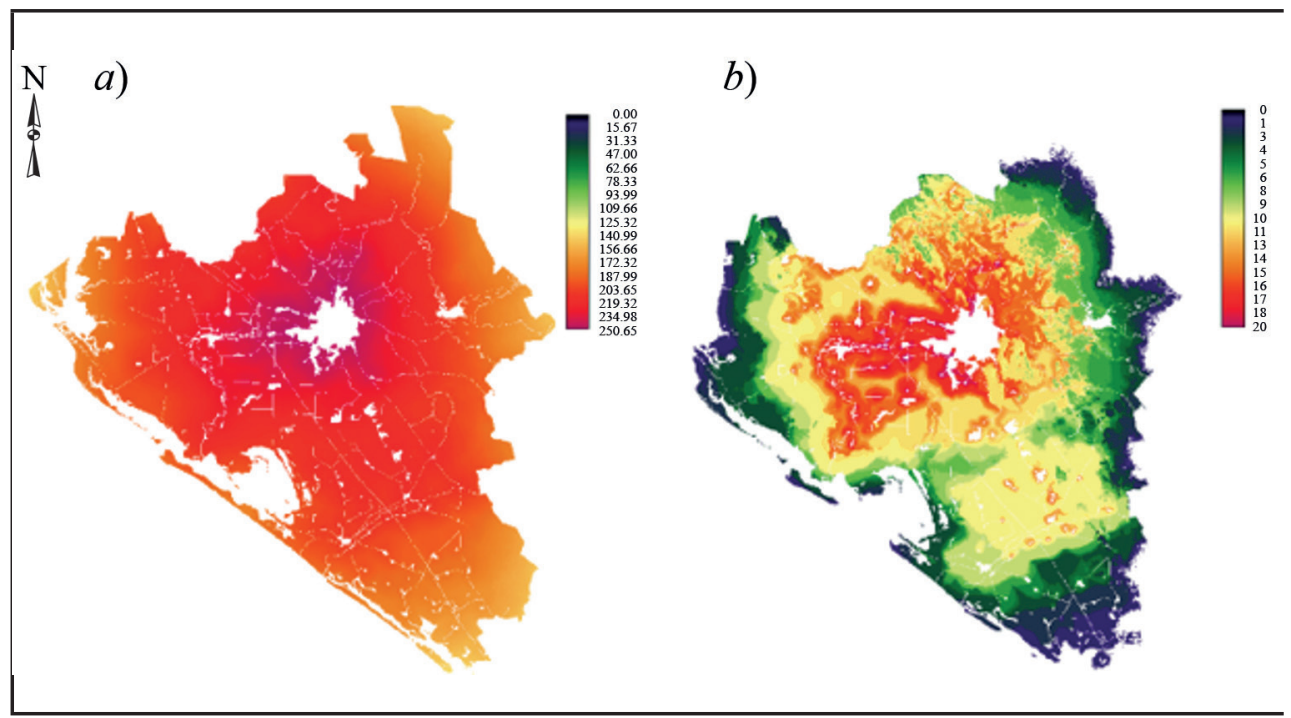

FIGURE 5

a) Aptitude scenario map 1 using OWA and $b$ ) frequency map of the 31 simulated maps Source: own elaboration.

The result is a map with 5 categories to house urban growth as: very high, high, average, low and very low, that, correspond to 225 (initial selection), 428 (distance of $500 \mathrm{~m}$ ), 144 (distance of $1 \mathrm{~km}$ ), 679 (distance to $2 \mathrm{~km}$ ) and 0 (other distance) pixels. In this case, at the moment of observing the only best category (very high), it is not possible to satisfy in the same way the previous analysis of total demand surface; however, at the moment to join the next best category (high), it is possible to increase the selection to 653 pixels (figure 6).

Moreover, a comparative analysis with the simulated areas was performed, which has the best capability to house urban growth against the planned urban area of the city, the result can be observed in figure 7 .

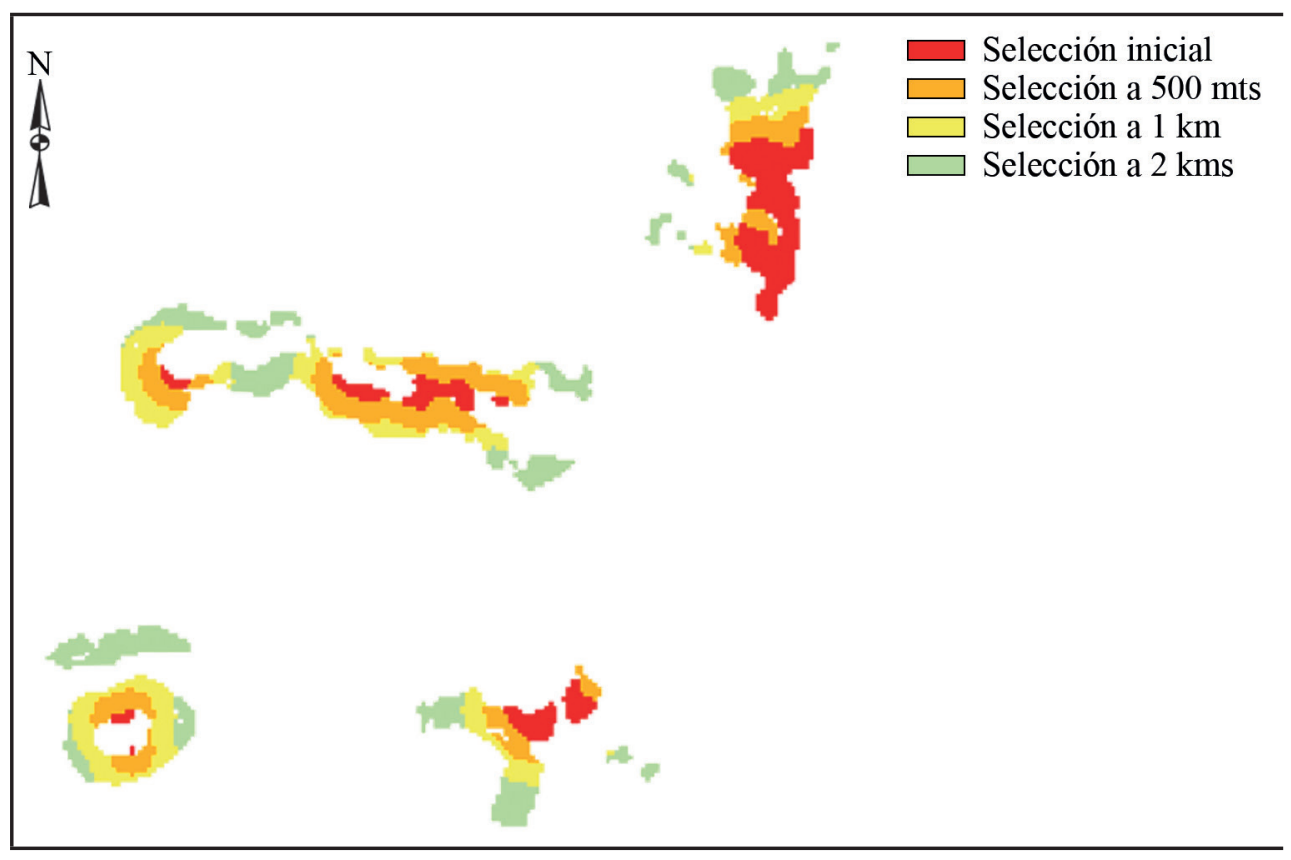

FIGURE 6

Final map with selection by distance with the categories of: initial selection, distance of $500 \mathrm{mts}, 1 \mathrm{~km}$ and $2 \mathrm{kms}$ Source: own elaboration. 


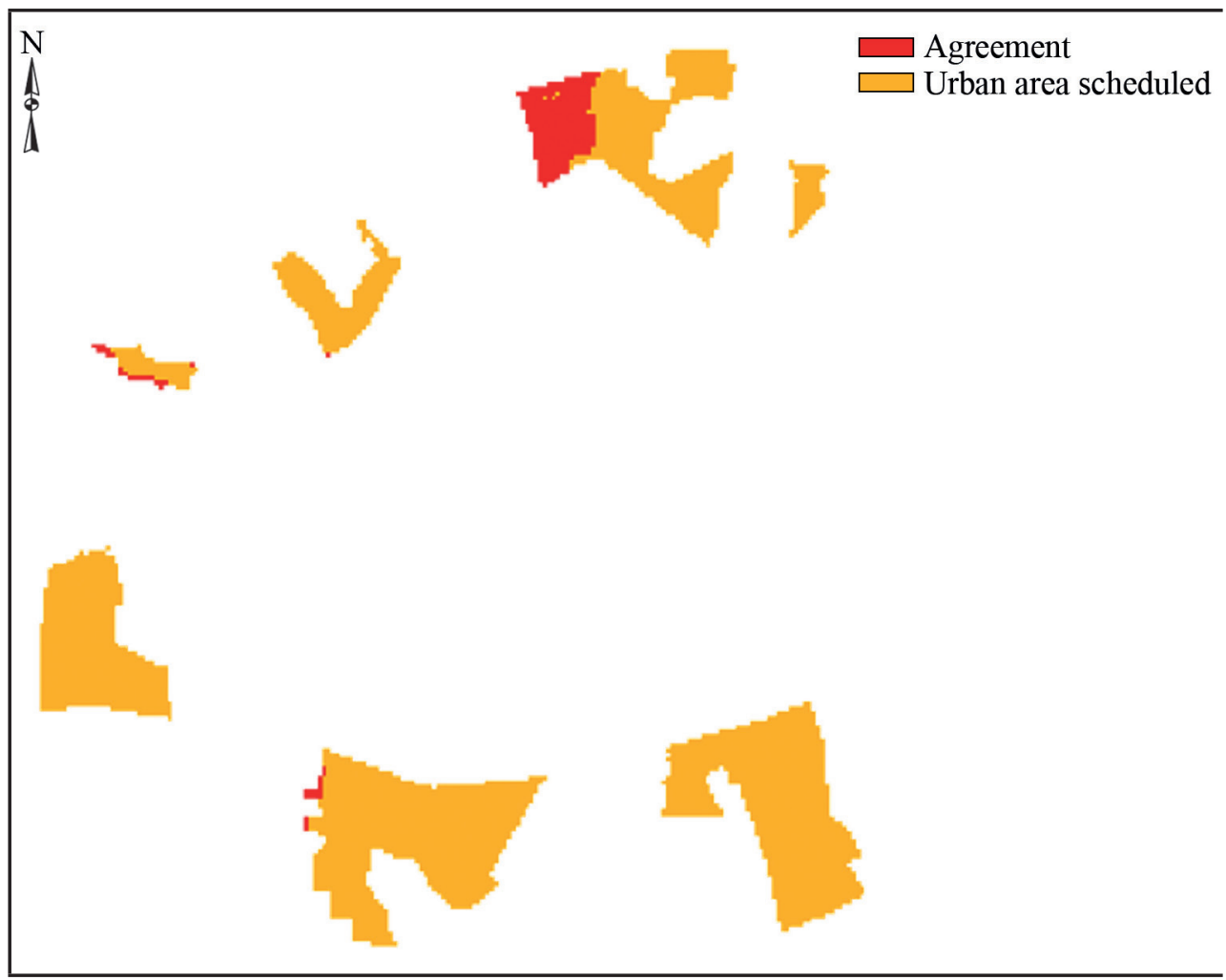

FIGURE 7

Consistency of selection by distance with the planned urban area Source: own elaboration.

\section{Discussion}

The sensibility analysis methodology proposed in this study was used for the identification of the most capable pixels to house new urban growths, considering the aptitude and distance. However, it is necessary to thoroughly analyze more cases, where it is required to simulate a great surface demand; this could underestimate the total necessary pixels.

Two forms for selecting a determined number of pixels for urban growth were proposed. In the case of the location of the prone areas to house urban growth, the classification was based on Natural Breaks. Later, such classification was improved with the consideration of the distances. The advantage of our proposal is that it is not just based on the individual aptitude or in the frequency it is shown; otherwise, both types of data are used and also the summation of the information of each pixel is added, having a result based on different statistical values; besides, the second proposal uses distance, in order to achieve a selection by proximity area. In both cases, the results more robust without considering only a selection by aptitude order of pixel or frequency order, which is, the most common selection technique.

\section{Conclusions}

Analyzing the most selected pixel map, it can be noticed that the maximum value that can have a pixel is 20 , due to the existence of pixels that appear in 20 of 31 proposed scenarios. In other words, these cells (areas) have $64.5 \%$ robustness against the weight variation.

The final map (NB and distance), showing the suitability of the selected pixels has four categories: initial selection, selection at $500 \mathrm{~m}$, selection at $1 \mathrm{~km}$ and selection at $2 \mathrm{~km}$ which contains a total of 669, 825, 782 and 925 ha respectively. And the total area selected, 11.6\% ( 372 ha) have a value of $20,55.3 \%$ have a value of 19 , 
$13.8 \%$ corresponds to the value of $18,13.6 \%$ appears with a value of 17 and $0.3 \%$ is observed with a value of 16 , these values correspond to the scenario frequency map.

The result obtained by the best selection, that is initial selection, satisfies a $97 \%$ of the total area needed for growth and has a concordance of $21.5 \%$ (146 ha) and its surface corresponds to the values of 20,19 and 17 with a percentage of $46.1 \%, 47.2 \%$ and $6.5 \%$ respectively.

On the other hand, if we compare all the categories of the final map with the urban area programmed, it is observed that, the total selection at $500 \mathrm{~m}$ (825 ha) coincides $13.1 \%$ ( $89 \mathrm{ha}$ ), of the selection at $1 \mathrm{~km}(782 \mathrm{ha})$ it agrees $10.9 \%$ ( $74 \mathrm{ha}$ ) and the agreement for selection at $2 \mathrm{~km}$ (925 ha) is $1.7 \%$ (12 ha), highlighting that a better way to find the most suitable pixels, is to use different statistical characteristics (aptitude, frequency and sum) and spatial (distance) of each pixel.

With these results, it can be detected that the best sites to house urban growth (by the year 2030), are the northern sites (the largest area) approaching the town of Mojolo, and contiguous to the urban core of Culiacan. In addition, it is also observed that the northwest area near the town of Culiacancito and southwest of Culiacan, have good suitability to adopt urban growth.

\section{Prospective analysis}

Because our territory will not support the trend of changes, it is necessary to evaluate different future scenarios, in order to further analyze the areas suitable for urban growth, so there is also the need to establish a better sensitivity analysis methodology to determine the level of reliability of the areas to be selected, in addition to obtain the impact of input factors at the spatial level. Considering the above, future models and scenarios are a useful tool to discuss the imbalances or benefits that cause different changes in the territory.

\section{REFERENCES}

Al-Shalabi, M. A., Mansor, S. B., Ahmed, N. B., \& Shiriff, R. (2006). GIS based multicriterio approach-es to housing site suitability assessment. XXIII International FIG Congress. Munich, Germany.

Anon. (2010). INEGI. Retrevied from http://www.inegi.org.mx/

Barredo, J. I., \& Gómez, M. D. (2008). Towards a set of IPCC SRES urban land use scenarios: Modelling urban land use in the Madrid region. In Modelling Environmental Dynamics (pp. 363-385). Springer, Berlin, Heidelberg.

Barredo, J., \& Bosque-Sendra, J. (2009). Comparison of multi-criteria evaluation methods integrated in geographical information systems to allocate urban areas. Departamento de Geografía, Universidad de Alcalá de Henares, España. Financiado por la Comisión Interministerial de Ciencia y Tecnología (Proyecto no. AMB 94-1017).

Boroushaki, S., \& Malczewski, J. (2008). Implementing an extension of the analytical hierarchy process using ordered weighted averaging operators with fuzzy quantifiers in ArcGIS. Computers and Geosciences, 32, 399-401.

Chang, N. B., Parvathinathan, G., \& Breeden, J. B. (2008). Combining GIS with fuzzy multicriteria decision-making for landfill siting in a fast-growing urban region. Journal of Environmental Management, 87(1), 139-153.

Comisión Europea. (1999). Estrategia territorial europea. Hacia un desarrollo equilibrado y sostenible de la UE. Retrieved form http://ec.europa.eu/regional_policy/sources/docoffic/official/reports/pdf/sum_es.pdf.

Corrales Barraza, G., Rocha Plata, W., Monjardin Armenta, S. A., Uriarte Adrián, J. D, \& Beltrán González, J. C. (2017). Diseño de un modelo de demanda de superficie para la simulación geoespacial de usos de suelo en Novolato y Culiacán, Sinaloa, México. Persona y Sociedad, 31(1), 9-26. 
Corrales Barraza, G. (2013). Análisis de cambio de uso de suelo para el estado de Sinaloa utilizando Sistemas de Información Geográfica (tesis de maestría). México: Universidad Autónoma de Sinaloa.

Drobne, S., \& Lisec, A. (2009). Multi-attribute decision analysis in GIS: Weighted linear combination and ordered weighted averaging. Informatics, 33(4).

Eastman, J. R. (2012). Idrisi Selva Manual 17. Clark University.

Feng, Y., Liu, M., Chen, L., \& Liu, Y.(2016). Simulation of dynamic urban growth with partial least squares regressionbased cellular automata in a GIS environment. ISPRS International Journal of Geo-Information, 5(12), 243.

Furtado, B. A., \& Eberhardt, I. D. R. (2015). A simple agent-based spatial model of the economy: Tools for policy. arXiv preprint arXiv:1510.04967.

Gómez, M., \& Barredo, J. (2005). Sistemas de Información Geográfica y evaluación multicriterio en la ordenación del territorio (segunda edición). RA-MA.

Gómez-Delgado, M., Aguilera Benavente, F., Barreira González, P., Bosque Sendra, J., \& Rodríguez Espinosa, V. M. (2014). Simulación prospectiva del crecimiento urbano en la Comunidad Autónoma de Madrid a partir de modelos basados en autómatas celulares y modelos basados en EMC.

Hu, Z., \& Lo, C. P. (2007). Modeling urban growth in Atlanta using logistic regression. Computers, Environment and Urban Systems, 31(6), 667-688.

IMPLAN. (2015). IMPLAN. Sinaloa, México. Retrevied from http://www.implancln.gob.mx/

INEGI. (2017). Uso de suelo y vegetación. México.

INEGI. (2014). Instituto Nacional de Estadística y Geografía (INEGI). México. Retrevied from http://www. inegi.org.mx/

Jenks, G. F. (1967). The data model concept in statistical mapping. International Yearbook of Cartography, 7 , 186-190.

Jiang, H. y Eastman, J. R. (2000). Application of fuzzy measures in multi-criteria evaluation in GIS. International Journal of Geographical Information Science, 14(2), 173-184.

Malczewski, J. (2002). Fuzzy screening for land suitability analysis. Geographical \& Environmental Modelling, 6(1), 27-39.

Malczewski, J., Chapman, T., Flegel, C., Walters, D., Shrubsole, D., \& Healy, M. A. (2003). GIS-multicriteria evaluation with ordered weighted averaging (OWA): Case study of developing watershed management strategies. Environment and Planning A, 35(10), 1769-1784.

Malczewski, J. (2004). GIS-based land-use suitability analysis: A critical overview. Progress in planning, 62(1), 3-65.

Malczewski, J. (2006). GIS-based multicriteria decision analysis: A survey of the literature. International Journal of Geographical Information Science, 20(7), 703-726.

Mogaji, K. A., Lim, H. S., \& Abdullah, K. (2014). Modeling groundwater vulnerability prediction using geographic information system (GIS)-based ordered weighted average (OWA) method and DRASTIC model theory hybrid approach. Arabian Journal of Geosciences, 7(12), 5409-5429.

Naghdizadegan, M., Behifar, M., \& Mirbagheri, B. (2013). Spatial deforestation modeling using cellular automata (Case study: Central Zagros Forests). International Archives of the Photogrammetry, Remote Sensing and Spatial Information Sciences, 1 .

Pearson, K. (1920). Notes on the history of correlation. Biometrika, 13(1), 25-45.

Phua, M.H., \& Minowa, M. (2005). A GIS-based multi-criteria decision-making approach to forest conservation planning at a landscape scale: a case study in the Kinabalu Area, Sabah, Malaysia. Landscape and Urban Planning, 71(2).

Plata, W., Gómez, M., \& Bosque, J. (2010). Desarrollo de modelos de crecimiento urbano óptimo para la 
Comunidad de Madrid. GeoFocus. Revista Internacional de Ciencia y Tecnología de la Información Geográfica, 10, 103-134.

Plata Rocha, W., Gómez-Delgado, M., Bosque-Sendra, J., Aguilar, J. M. (2013). Análisis de sensibilidad para un modelo de simulación de crecimiento urbano. Propuesta metodológica explícitamente especial. GeoFocus, 13(2), 158-178.

Qureshi, M. E., Harrison, S. R., \& Wegener, M. K. (1999). Validation of multicriteria analysis models. Agricultural Systems, 62(2), 105-116.

Roldán López, H., (2006). La urbanización metropolitana de Culiacán. México: Gobierno de Sinaloa, Fontamara.

Roura-Pascual, N., Reiner, M. K., Richardson, D. M., \& Hui, C. (2010). Spatially-explicit sensitivity analysis for conservation management: Exploring the influence of decisions in invasive alien plant management. $\mathrm{Di}$ versity and Distributions, 16(3), 426-438.

Saaty, R. W. (1987). The analytic hierarchy process-what it is and how it is used. Mathematical modelling, 9(3-5), 161-176.

Tan, R., Liu, Y., Zhou, K., Jiao, L., \& Tang, W. (2015). A game-theory based agent-cellular model for use in urban growth simulation: A case study of the rapidly urbanizing Wuhan area of central China. Computers, Environment and Urban Systems, 49, 15-29.

Van der Heijden, K. (2005). Scenarios: The art of strategic conversation (2nd ed.). Chichester: John Wiley \& Sons.

\section{ANNEXED}

TABLE 1

Variables employed for modeling factor in the scenarios simulation

\begin{tabular}{|c|c|c|c|}
\hline Variables & Description/Date & Source/Scale & Model factor \\
\hline $\begin{array}{l}\text { Irrigation agriculture and moisture } \\
\text { Irrigation rainforest agriculture } \\
\text { Human settlement } \\
\text { Forestry } \\
\text { Pastureland } \\
\text { Jungle } \\
\text { Other types }\end{array}$ & $\begin{array}{l}\text { Reclassification produ- } \\
\text { ced fot the simulation. } \\
\text { Based on the vegetation } \\
\text { and land-use map (VLU) } \\
\text { Serie V. Year 2011. }\end{array}$ & $\begin{array}{l}\text { Compiled by } \\
\text { authors, based on } \\
\text { INEGI data. Scale: } \\
1: 250,000\end{array}$ & $\begin{array}{l}\text { Proximity of irrigation agriculture } \\
\text { Proximity of rainforest agriculture } \\
\text { Proximity of a human settlement } \\
\text { Proximity of pastureland } \\
\text { Proximity of natural vegetation }\end{array}$ \\
\hline Soil type & $\begin{array}{l}\text { Represents the soil type } \\
\text { existent in the study area. } \\
\text { Year } 2007 .\end{array}$ & $\begin{array}{l}\text { INEGI. Scale: } \\
1: 250,00\end{array}$ & \\
\hline $\begin{array}{l}\text { Altitude } \\
\text { Slope }\end{array}$ & $\begin{array}{l}\text { Digital Terrain Model } \\
\text { (DTM). The slope was } \\
\text { obtained from the DTM. } \\
\text { Year } 2013 .\end{array}$ & INEGI. Scale: 90 m & Slope \\
\hline $\begin{array}{l}\text { Rivers } \\
\text { Canals }\end{array}$ & $\begin{array}{l}\text { It was employed for } \\
\text { calculate the distance } \\
\text { to the rivers and wa- } \\
\text { terways. Year } 2010 \text { for } \\
\text { rivers. Year } 2005 \text { for } \\
\text { waterways. }\end{array}$ & $\begin{array}{l}\text { INEGI. Scale: } \\
1: 25,000,1: 100,000\end{array}$ & Proximity to rivers \\
\hline Roads & $\begin{array}{l}\text { It was employed for } \\
\text { calculate the distance to } \\
\text { the roads. Year } 2014 \text {. }\end{array}$ & $\begin{array}{l}\text { INEGI. Scale: } \\
50,000\end{array}$ & Proximity to roads \\
\hline
\end{tabular}

Source: own elaboration. 